Kartika, et al/Jurnal Ekonomi Syariah Teori dan Terapan Vol. 6 No. 2 Februari 2019: 353-371; KEBIJAKAN KEPEMIMPINAN WALIKOTA SURABAYA DALAM MENGAMBIL KEPUTUSAN DI BIDANG EKONOMI YANG BERBASIS MAQASHID SYARIAH

\title{
KEBIJAKAN KEPEMIMPINAN WALIKOTA SURABAYA DALAM MENGAMBIL KEPUTUSAN DI BIDANG EKONOMI YANG BERBASIS MAQASHID SYARIAH
}

\author{
Dara Wira Kartika \\ Departemen Ekonomi Syariah-Fakultas Ekonomi dan Bisnis-Universitas Airlangga \\ Email: darawiral@gmail.com
}

\section{R.Moh.Qudsi Fauzi}

Departemen Ekonomi Syariah-Fakultas Ekonomi dan Bisnis-Universitas Airlangga Email: qudsifauzy1@gmail.com

\begin{abstract}
:
This study aims to analyze the Surabaya Mayor's leadership policy in making decisions related to the economy from the perspective of maqashid sharia, namely in fulfilling the basic needs of religion, soul, mind, lineage and wealth. This study uses a qualitative method with a case study approach. The method used in this study is domain analysis to look at the mayor's policies in Surabaya with the fulfillment in the economy seen from the side of the Surabaya city budget. The results of this study are, when viewed from the written budget data, it is not balanced between the fulfillment of maqashid sharia. However, judging from the way the mayor of Surabaya in making policies was in accordance with maqashid sharia.

Keywords: Public Policy, The Mayor's Leadership in Surabaya, Mayor of Surabaya, Maqashid Sharia
\end{abstract}

\section{PENDAHULUAN}

Fenomena kepemimpinan dalam masyarakat sekarang ini seringkali dipengaruhi oleh kepemimpinan yang bersifat material dan politis. Kondisi ini terlihat pada beberapa kepemimpinan di wilayah Indonesia seperti kepemimpinan di daerah DKI Jakarta seperti kasus mantan Gubernur Ahok tahun 2017. Kepemimpinan di wilayah surabaya seperti Tri Rismaharini yang fenomenal dengan kebijakan-kebijakan yang tegas dalam memajukan wilayahnya. Isu-isu yang sering dihadapi dalam kepemimpinan tersebut seringkali dikaitkan dengan kepemimpinan politik maupun tuntutan material dari masyarakatnya. Sehingga di era yang sudah berkembang pesat seperti sekarang, pemimpin pada praktiknya hanyalah sebatas slogan dan teori saja namun pada kenyataannya manusia yang dipilih sebagai pemimpin tersebut belum dapat dianggap dan belum menampilkan dirinya sebagai pimpinan yang patut dijadikan contoh bagi pengikut maupun bawahannya.

Definisi kepemimpinan dapat sesuai dengan perspektif individualnya dan aspek gejala yang paling menarik perhatiannya sehingga dapat disimpulkan berdasarkan ciri-ciri, perilaku, pengaruh, pola interaksi, hubungan peran, dan posisi jabatan administratif (Stogdill,1974 h.259).

Kemudian, menurut Jacobs \& Jaques (1990, h.26) Kepemimpinan adalah proses memberikan tujuan (arahan yang berarti) ke usaha yang kolektif, yang menyebabkan adanya usaha yang dikeluarkan untuk mencapai suatu tujuan Kesimpulannya adalah, seorang pemimpin haruslah mempunyai

1) Jurnal ini merupakan bagian dari skripsi Dara Wira Kartika, NIM: 041411431145, yang diuji pada tanggal 18 Januari 2019 
Kartika, et al/Jurnal Ekonomi Syariah Teori dan Terapan Vol. 6 No. 2 Februari 2019: 353-371; KEBIJAKAN KEPEMIMPINAN WALIKOTA SURABAYA DALAM MENGAMBIL KEPUTUSAN DI BIDANG EKONOMI YANG BERBASIS MAQASHID SYARIAH

karakteristik tertentu sehingga mempunyai suatu kemampuan dan keunikan tersendiri untuk mencapai suatu tujuan tertentu terutama untuk kesejahteraan rakyatnya.

Dalam pandangan islam, ketika pada masa kepemimpinan Rasulullah terdapat empat sifat yang harus ada dalam diri seorang pemimpin yaitu:

1. Ash-Shidq, yaitu kebenaran dan kesungguhan dalam berucap, bersikap, dan juga berjuang untuk melaksanakan tugas yang diembannya.

2. Al-Amanah, yaitu kepercayaan yang senantiasa menjadikan ia menjaga dan memelihara apa yang diserahkan kepadanya dengan sebaik-baiknya.

3. Al-Fathanah, yaitu kecerdasan yang menghasilkan kemampuan dalam menghadapi dan juga menanggulangi permasalahanpermasalahan yang muncul sewaktu-waktu.

4. At-Tabligh, yaitu jujur dan bertanggung jawab.

Sementara itu Ibnu Khaldun menyatakan bahwa ketika hakikat kedudukan ini sudah kami jelaskan sebelumnya, bahwa ia (imamah) adalah wakil dari Pemilik syariat dalam hal menjaga agama dan mengatur dunia dengannya (agama), maka ia disebut khilafah dan imamah. Sedangkan orang yang melaksanakannya disebut khalifah atau imam.

$$
\text { Ketika suatu masyarakat }
$$
membutuhkan seorang pemimpin, maka seorang yang paham akan realitas masyarakatlah yang pantas mengemban amanah kepemimpinan tersebut. Pemimpin tersebut harus dapat membawa masyarakat menuju kesempurnaan yang sesungguhnya. Watak manusia yang bermasyarakat ini merupakan kelanjutan dari karakter individu yang menginginkan perkembangan dirinya menuju pada kesempurnaan yang lebih dan kehidupan bermasyarakat yang tentram dan sejahtera.

Perkembangan ekonomi global sekarang ini memiliki implikasi terhadap kesejahteraan negara. Sehingga peran pemimpin sangatlah penting dalam suatu organisasi maupun negara. Secara global dan khususnya negara negara di industri maju, pertumbuhan ekonomi telah memperkuat dan meningkatkan integrasi sosial. Namun demikian, menurut analisis Edi Suharto, pada banyak negara berkembang globalisasi dan ekonomi pasar bebas telah memperlebar kesenjangan, menimbulkan kerusakan lingkungan, menggerus budaya dan bahasa lokal, serta memperparah kemiskinan.

Surabaya sebagai salah satu kota terbesar kedua di Indonesia setelah Jakarta yang juga disebut sebagai kota pahlawan ini mengalami perkembangan yang pesat, mulai dari berbagai sarana prasarana hingga transportasi serta memiliki jumlah penduduk berdasarkan data terakhir menurut Badan Pusat Statistik Bulan Agustus 2017 sebanyak 3.057.766 
Kartika, et al/Jurnal Ekonomi Syariah Teori dan Terapan Vol. 6 No. 2 Februari 2019: 353-371; KEBIJAKAN KEPEMIMPINAN WALIKOTA SURABAYA DALAM MENGAMBIL KEPUTUSAN DI BIDANG EKONOMI YANG BERBASIS MAQASHID SYARIAH

jiwa yang terdiri dari 1.526.583 laki-laki dan 1.531.183 perempuan. Sedangkan data kemendagri tercatat penduduk Surabaya sebanyak 2.827.892 orang dengan luas wilayah 33.306,30 Ha. Berdasarkan data penduduk tersebut tentunya Surabaya merupakan salah satu kota besar yang memiliki banyak penduduk sehingga permasalahan yang ada juga semakin kompleks dan beragam. Mulai dari permasalahan ekonomi, pendidikan, keturunan dan lain-lain.

Berbagai fenomena di Surabaya yang tentunya telah terjadi dan walikota yang berperan dalam penyelesaian masalah tersebut tidak lain adalah Ibu Tri Rismaharini, salah fenomena yang menjadi topik yang sempat hangat adalah ditutupnya Gang Dolly yang merupakan sebuah kawasan lokalisasi prostitusi yang konon terbesar di Asia Tenggara pada 18 Juni 2014. Kebijakan tersebut merupakan hal yang sangat besar pada saat itu karena keputusan yang dibuat oleh Risma merupakan keputusan yang sangat berani. Tentunya banyak yang mendukung keputusan beliau untuk menutup prostitusi tersebut akan tetapi, banyak yang menentang karena lokasi tersebut merupakan lahan mata pencaharian masyarakat terutama yang tinggal di sekitar lokalisasi tersebut. Bahkan Risma sendiri sempat mengalami berbagai macam tekanan dari orangorang yang tidak sependapat dengan kebijakan beliau. Penutupan ini bukanlah hal yang sederhana, karena selama puluhan tahun lokalisasi tersebut berdiri dan tak ada yang mampu menutupnya.

Awalnya memang tidak mudah untuk mengubah image Gang Dolly yang telah melekat sekian lama dibenak warga Surabaya tetapi, dengan usaha melakukan pendekatan kepada warga sekitar Gang Dolly, eks mucikari, maupun eks pekerja seks ancaman tersebut berubah menjadi sebuah harapan terutama untuk masa depan masyarakat Surabaya dengan cara membangun pemberdayaan ekonomi di sekitar wilayah Gang Dolly sehingga semua warga eks Dolly maupun mucikari telah berdaya secara ekonomi. Walikota surabaya Tri rismaharini membuka festival Dolly yang kini menjadi kampung yang kaya dengan kreativitas warganya. Saat ini, terus dilakukan pemberdayaan terhadap mantan mucikari dan eks pekerja seks komersial. Mulai dari membatik, membuat baju, menjahit, konveksi, tas, hingga perajin sepatu. Tidak hanya itu, mereka juga membuka warung makan dan aneka kuliner. Sehingga sekarang, di wilayah tersebut telah terjadi suatu perubahan yang sangat besar mulai dari perekonomian dan kehidupan warga sekitar dengan kegiatan yang tentunya memberi efek positif (Sumber :http://surabaya.tribunnews.com diakses pada : Maret 2018).

Selain fenomena Gang Dolly, salah satu prestasi yang membanggakan dari surabaya yaitu upaya pemerintah kota surabaya untuk menciptakan ruang terbuka hijau. Banyak lahan-lahan kosong 
ditengah kota, kini dijadikan sebagai taman kota atau hutan kota. Dengan total luas wilayah surabaya $33.306,30$ ha setidaknya Surabaya mempunyai lahan terbuka hijau seluas 4.8951.52 ha. Berkat usaha dan kerja keras yang dilakukan pemerintah kota surabaya sudah mampu mengembalikan fungsi ruang terbuka hijau selayaknya. Fungsi sebagai filter udara, daerah tangkapan air mengurangi kadar zat pencemar udara dan menambah kenyamanan kota sudah bisa dirasakan. Termasuk fungsi untuk mengurangi efek-efek dermatological health pada pusat-pusat bangunan tinggi dan polusi udara dari kendaraan bermotor yang berkibat pada timbulnya anomali pergerakan zat pencemar udara yang berdampak destruktif baik terhadap fisik bangunan maupun makhluk hidup serta memberi ketenangan jiwa

(Sumber:

https://fasilitasumumsby.wordpress.com/ta man/diakses pada : Bulan Maret 2018).

Lalu, pemerintah kota (selanjutnya disebut pemkot) surabaya melalui Dinas Pengendalian Penduduk, Pemberdayaan Perempuan, dan perlindungan anak (DP5A), terus memperhatikan dan memfasilitasi kebutuhan anak-anak yang mengalami permasalahan kesejahteraan sosial.

Lalu pada Tahun 2015, Badan Amil Zakat Infaq Sadaqah kota Surabaya dibekukan Walikota Surabaya karena dianggap menyalahi aturan dalam pengelolaan dana sosial sejak beberapa tahun terakhir. Hal ini diketahui Walikota
Surabaya Tri Rismaharini, termuat dalam pertanggungjawaban alokasi Badan Amil Zakat yang cenderung berat sebelah alokasinya. Sebanyak 50 persen lebih dana digunakan untuk operasional pengurus, harusnya sebagai lembaga sosial harus kebalikannya. Dana sosial harus lebih banyak. Karena dibekukan, Risma menahan dana hibah dari pemkot sebesar Rp 300 juta. Risma bersedia menekan pencairan dana tersebut jika pengurus Badan Amil Zakat merombak tata kelola penyaluran dana sosial, dengan mengedepankan penyaluran dana sosial lebih besar daripada dana operasional pengurus. Karena, Badan amil zakat dipercaya masyarakat untuk menyalurkan dana sosial bagi masyarakat. Selain menghimpun dana dari masyarakat, Badan amil zakat juga menghimpun dana infak dan sedekah dari pegawai pemkot surabaya. Setiap bulannya, ada sekitar Rp 20 juta hingga Rp 30 juta dana yang dikumpulkan dari pegawai Pemkot surabaya di luar dana yang dihimpun masyarakat umum (Sumber: http://kompas.com diakses pada : Bulan Maret 2018).

$$
\text { Salah satu tujuan dari }
$$

pembangunan ekonomi dalam perspektif Ekonomi Islam adalah terpenuhinya terciptanya keadilan distribusi; berarti tercapainya minimal dalam pembangunan adalah terpenuhinya hak dasar kebutuhan ekonomi individu masyarakat, sebagai jaminan pemeliharaan maqasyid syariah, yang menurut As syatibi terdiri dari lima 
Kartika, et al/Jurnal Ekonomi Syariah Teori dan Terapan Vol. 6 No. 2 Februari 2019: 353-371; KEBIJAKAN KEPEMIMPINAN WALIKOTA SURABAYA DALAM MENGAMBIL KEPUTUSAN DI BIDANG EKONOMI YANG BERBASIS MAQASHID SYARIAH

maslahat pokok yaitu Agama, Jiwa, Akal, Keturunan dan Harta. Tidak terpenuhinya hak dasar kebutuhan ekonomi disebabkan buruknya distribusi, akan menimbulkan problem ekonomi, yang jauh dari pengertian kondisi sejahtera.

Maqashid syariah adalah salah satu aspek penting dalam ekonomi Islam dan salah satu tujuan dari ekonomi islam untuk merealisasikan falah kepada umat manusia dimuka bumi melalui pendayagunaan sumber-sumber daya yang dianugerahkan oleh Allah kepada manusia dengan aturan-aturan yang telah ditetapkan oleh Allah Swt. Maqashid Syariah mempunyai beberapa pendekatan menurut Kamali (2008) yaitu:

a. Pendekatan tekstual yang jelas, perintah dan larangannya.. Pendekatan ini lebih difokuskan kepada pendekatan teks (AlQuran dan As-sunnah).

b. Pendekatan illat, yaitu proses ijtihad menggunakan metode qiyas yaitu menganalogikan sebuah kasus hukum (furu') yang baru dengan yang lama (usul) dengan menghadirkan alasan atau sebab ('illat) hukumnya.

c. Pendekatan ijtihad dengan premis untuk merealisasikan manfaat (maslahah) dan mencegah kerusakan (mafsadah).

Sehingga dengan latar belakag tersebut maka dibentuklah rumusan masalah bagaimana Kepemimpinan Walikota Surabaya dalam Membuat Kebijakan yang berkaitan dengan bidang ekonomi dilihat dari perpektif Maqashid Syariah?

\section{LANDASAN TEORI}

\section{Kepemimpinan}

Menurut Daniel C. Fledman dan Hugh J. Arnold mengatakan bahwa kepemimpinan pada dasarnya melibatkan seorang pemimpin secara sadar mencoba mendapatkan orang lain (pengikut) untuk mengerjakan sesuatu yang pemimpin inginkan untuk dikerjakan oleh pengikutnya (dalam Sutarto 1989 : 22). Kepemimpinan dapat dilihat sebagai proses mengarahkan dan mempengaruhi aktivitas yang berkaitan dengan kegiatan organisasi, maka terdapat tiga implikasi yang diterapkan yaitu:

1. Pertama, kepemimpinan harus melibatkan orang lain. Kedua, Semakin besar sumber kekuasaan, semakin besar potensinya untuk menjadi pemimpin yang efektif.

2. Ketiga, kepemimpinan sebagai kemampuan untuk menggunakan berbagai bentuk kekuasaan untuk mempengaruhi perilaku pengikut melalui sejumlah cara. Untuk alasan ini diharapkan pemimpin memiliki kewajiban khusus untuk mempertimbangkan etika dari keputusan mereka (Sartono, 2004:78-79).

Pemimpin dan kepemimpinan adalah sesuatu hal yang tidak dapat dipisahkan dan merupakan sebuah kesatuan. Seorang pemimpin harus mempunyai jiwa kepemimpinan, yang mana terbentuk dari suatu proses dari 
Kartika, et al/Jurnal Ekonomi Syariah Teori dan Terapan Vol. 6 No. 2 Februari 2019: 353-371; KEBIJAKAN KEPEMIMPINAN WALIKOTA SURABAYA DALAM MENGAMBIL KEPUTUSAN DI BIDANG EKONOMI YANG BERBASIS MAQASHID SYARIAH

waktu ke waktu hingga akhirnya akan mengkristal dalam suatu bentuk karakteristik kepemimpinan. Seseorangyang mempunyai jiwa kepemimpinan, dengan usaha yang gigih akan dapat membantu lahirnya penegasan sikap kepemimpinan yang ada dalam dirinya (Fahmi : 2012, 16).

\section{Kebijakan}

Kebijakan dapat didefinisikan sebagai serangkaian rencana program, aktivitas, aksi, keputusan, sikap, untuk bertindak maupun tidak bertindak yang dilakukan oleh para pihak (aktor-aktor), sebagai tahapan untuk penyelesaian masalah yang dihadapi. Penetapan kebijakan merupakansuatu faktor penting bagi organisasi untuk mencapai tujuannya (Iskandar, 2012).

Berkenaan dengan pelaksanaan kebijakan, Islamy (2010) mengemukakan pengertian kebijakan publik, sebagai berikut:

a. Kebijakan negara dalam bentuk awalnya berupa ketetapan tindakantindakan pemerintah.

b. Kebijakan negara itu tidak cukup hanya dinyatakan, tetapi harus dilaksanakan dalam bentuk yang nyata.

c. Kebijakan negara yang baik untuk melakukan sesuatu atau tidak melakukan sesuatu dilandasi dengan maksud dan tujuan tertentu.

d. Kebijakan negara harus senantiasa ditujukan bagi pemenuhan kepentingan seluruh anggota masyarakat. Pelaksanaan kebijakan merupakan kegiatan lanjutan dari proses perumusan dan penetapan kebijakan. Sehingga pelaksanaan kebijakan dapat dimaknai sebagai tindakan-tindakan yang dilakukan, baik oleh individu maupun kelompok pemerintah.

Secara luas, pelaksanaan kebijakan digambarkan sebagai apa yang ditetapkan secara jelas oleh pembuat kebijakan (pemerintah) yang akan memiliki dampak tertentu. Jann \& Wegrich (2007) menyebutkan bahwa pelaksanaan kebijakan akan mencakup unsur inti sebagai berikut:

1. Spesifikasi dari rincian program, yaitu bagaimana dan di mana lembaga atau organisasi harus menjalankan program, dan bagaimana hukum atau program ditafsirkan;

2. Alokasi sumberdaya, yaitu bagaimana anggaran didistribusikan, personil yang akan melaksanakan program dan organisasi yang bertanggung jawab atas pelaksanaan program.

3. Keputusan, yaitu bagaimana keputusan akan dilakukan.

Proses pelaksanaan kebijakan tidak hanya menyangkut perilaku badanbadan administratif/ pemerintahan yang bertanggung jawab untuk melaksanakan program dan menimbulkan ketaatan pada diri kelompok sasaran, melainkan juga menyangkut jaringan pada kekuatan-kekuatan politik, ekonomi, dan sosial, yang secara langsung maupun tidak langsung dapat mempengaruhi perilaku dari para pihak yang terlibat (stakeholders). Kesalahan atau ketidaksempurnaan suatu kebijakan 
Kartika, et al/Jurnal Ekonomi Syariah Teori dan Terapan Vol. 6 No. 2 Februari 2019: 353-371; KEBIJAKAN KEPEMIMPINAN WALIKOTA SURABAYA DALAM MENGAMBIL KEPUTUSAN DI BIDANG EKONOMI YANG BERBASIS MAQASHID SYARIAH

biasanya akan dapat dievaluasi setelah kebijakan itu dilaksanakan, begitu juga keberhasilan pelaksanaan kebijakan dapat dianalisa pada akibat yang ditimbulkan sebagai hasil pelaksanaan kebijakan. Penilaian atas kebijakan dapat mencakup isi kebijakan, pelaksanaan kebijakan, dan dampak kebijakan.

Mengenai keberhasilan kebijakan publik, Islamy (2010) menyatakan bahwa suatu kebijakan negara akan efektif apabila dilaksanakan dan memberikan dampak positif bagi masyarakat, dengan kata lain, tindakan atau perbuatan manusia yang menjadi anggota-anggota masyarakat bersesuaian dengan yang diinginkan oleh pemerintah atau negara.

\section{Aspek-Aspek yang Mempengaruhi}

\section{Pelaksanaan Kebijakan Publik}

Menurut Edwards III, pelaksanaan kebijakan dapat diartikan sebagai bagian dari tahapan proses kebijaksanaan, yang posisinya berada diantara tahapan penyusunan kebijaksanaan dan konsekuensi-konsekuensi yang ditimbulkan oleh kebijaksanaan tersebut (output, outcome). Lebih lanjut, Edward III mengidentifikasikan aspek-aspek yang diduga kuat berkontribusi pada pelaksanaan kebijakan, yaitu: komunikasi, sumberdaya, disposisi atau sikap pelaksana, dan struktur birokrasi. Keempat aspek mempengaruhi pelaksanaan kebijakan, baik secara langsung maupun tidak secara langsung, dan masingmasing aspek saling berpengaruh terhadap aspek lainnya (Wahyudi, 2016).

\section{a. Kewenangan/ Struktur Birokrasi}

Kewenangan merupakan otoritas/ legitimasi bagi para pelaksana dalam melaksanakan kebijakan yang ditetapkan secara politik (Afandi \& Warjio, 2015). Kewenangan ini berkaitan dengan struktur birokrasi yang melekat pada posisi/ strata kelembagaan atau individu sebagai pelaksana kebijakan.

\section{b. Komunikasi}

Komunikasi adalah aktivitas yang mengakibatkan orang lain menginterprestasikan suatu ide/ gagasan, terutama yang dimaksudkan oleh pembicara atau penulis melalui sesuatu sistem yang biasa (lazim) baik dengan simbol-simbol, signal-signal, maupun perilaku (Wardhani, Hasiolan, \& Minarsih, 2016). Komunikasi mempengaruhi pelaksanaan kebijakan publik, dimana komunikasi yang tidak baik dapat menimbulkan dampak-dampak buruk bagi pelaksanaan kebijakan. Dimensi komunikasi yang dapat mempengaruhi pelaksanaan kebijakan publik diantaranya: transmisi, konsistensi, dan kejelasan (Winarno, 2012).

\section{c. Sumber daya}

Pelaksanaan kebijakan harus ditunjang oleh ketersediaan sumberdaya (manusia, materi, dan metoda). Pelaksanaan kebijakan publik perlu dilakukan secara cermat, jelas, dan konsisten, tetapi jika para pelaksana kekurangan sumberdaya yang diperlukan, maka pelaksanaaan kebijakan akan cenderung tidak dapat dilaksanakan secara efektif. Tanpa dukungan 
Kartika, et al/Jurnal Ekonomi Syariah Teori dan Terapan Vol. 6 No. 2 Februari 2019: 353-371; KEBIJAKAN KEPEMIMPINAN WALIKOTA SURABAYA DALAM MENGAMBIL KEPUTUSAN DI BIDANG EKONOMI YANG BERBASIS MAQASHID SYARIAH

sumberdaya, kebijakan hanya akan menjadi dokumen yang tidak diwujudkan untuk memberikan pemecahan masalah yang ada di masyarakat, atau upaya memberikan pelayanan pada masyarakat. Dengan demikian, sumberdaya merupakan faktor penting dalam melaksanakan kebijakan publik. Sumberdaya dalam pelaksanaan kebijakan publik diantaranya: staf yang memadai, informasi, pendanaan, wewenang, dan fasilitas pendukung lainnya (Afandi \& Warjio, 2015).

\section{d. Disposisi atau sikap dari pelaksana}

Disposisi adalah watak dan karakteristik yang dimiliki oleh pelaksana kebijakan, seperti komitmen, disiplin, kejujuran, kecerdasan, dan sifat demokratis (Wahab, 2010). Apabila pelaksana kebijakan memiliki disposisi yang baik, maka dia diduga kuat akan menjalankan kebijakan dengan baik, sebaliknya apabila pelaksana kebijakan memiliki sikap atau cara pandang yang berbeda dengan maksud dan arah dari kebijakan, maka dimungkinkan proses pelaksanaan kebijakan tersebut tidak akan efektif dan efisien. Disposisi atau sikap para pelaksana akan menimbulkan dukungan atau hambatan terhadap pelaksanaan kebijakan tergantung dari kesesuaian kompetensi dan sikap dari pelaksanan. Karena itu, pemilihan dan penetapan personalia pelaksana kebijakan dipersyaratkan individu-individu yang memiliki kompetensi dan dedikasi yang tepat pada kebijakan yang telah ditetapkan (Afandi \& Warjio, 2015).

\section{Kepemimpinan dalam Islam}

Kepemimpinan yang harus dimiliki oleh seorang pemimpin adalah kepemimpinan yang dimana seseorang tidak hanya berbicara, namun juga mampu untuk memberikan keteladanan bagi yang dipimpinnya. Sebuah dosa besar apabila seorang pemimpim mengatakan atau menyanggupi sesuatu, akan tetapi dia sendiri tidak dapat melaksanakan, baik dalam pandangan Allah maupun pandangan masyarakat.

Menepati janji merupakan suatu perwujudan dari iman yang kuat dan budi pekerti yang baik serta sikap yang berkemanusiaan yang tertanam pada diri seorang pemimpin, menimbulkan kepercayaan dan juga penghormatan dari masyarakat. Jadi, itu adalah gambaran karakter dari pemimpin Islam.

\section{Maqashid Syariah}

\section{Pengertian Maqashid Syariah}

Secara etimologi maqashid alsyariah terdiri dari dua kata, yakni maqashid dan syariah. Maqashid adalah bentuk jamak dari maqshud yang berarti kesengajaan, atau tujuan. Kemudian syariah artinya jalan menuju air, atau bisa dikatakan dengan jalan menuju ke arah sumber kehidupan.

Menurut Al-Imam Al-Ghazali yang dimaksud dengan maqashid syariah yaitu penjagaan terhadap maksud dan tujuan syariah dalam upaya untuk bertahan hidup, serta menahan dari faktor-faktor yang memicu suatu kerusakan dan mendorong terciptanya kesejahteraan. 
Kemudian, Al-Imam Al-Syathibi mengelompokkan al-Maqashid menjadi dua yaitu pertama yaitu yang berkaitan dengan maksud Allah selaku pencipta syariah itu sendiri dan yang kedua berkaitan dengan maksud mukallaf. Maksudnya yaitu menghindari kerusakankerusakan yang ada di dalam dunia, maka haruslah ada penjelaan antara kemaslahatan (maslahah) dan kerusakan (mafsadah).

Dapat disimpulkan bahwa Maqashid al-syariah adalah maksud Allah selaku pembuat syari'ah untuk memberikan kemaslahatan kepada manusia. Yaitu dengan terpenuhinya kebutuhan dharuriyat, hajiyah dan tahsiniyah agar manusia bisa hidup dalam kebaikan dan dapat menjadi hamba Allah yang baik.

\section{Tujuan Maqashid Syariah}

Menurut Ibn Qayyim al-Jawziyyah dalam Jasser Audah, menyebutkan Maqashid Syariah adalah suatu kebijakan (hikmah) dan tercapainya perlindungan bagi setiap orang pada kehidupan dunia dan akhirat. Jadi setiap aturan yang mengatasnamakan kedamaian dengan pertengkaran, kebaikan dengan keburukan, kebijakan dengan kebohongan adalah suatu aturan yang tidak berdasarkan syariah walaupun hal tersebut diklaim sebagai interpretasi yang benar.

Kemaslahatan yang hendak dicapai oleh syari'ah bersifat umum dan universal yang artinya bahwa hal tersebut bukan hanya untuk individu semata secara pribadi, melainkan juga seluruh manusia secara keseluruhan, yang berarti kemaslahatan itu bukanlah untuk jangka waktu tertentu saja tetapi untuk sepanjang waktu dan sepanjang kehidupan manusia.

Maqashid syariah bertujuan untuk memegakkan kemaslahatan manusia sebagai makhluk sosial, yang mana ia harus bertanggung jawab atas dirinya sendiri dan juga bertanggung jawab pada Allah SWT. Kemudian untuk dilaksanakan agar keadilan dapat ditegakkan dan kesejahteraan dapat diwujudkan.

\section{Kerangka Maqashid Al-Syariah}

Ada lima unsur pokok yang harus diperhatikan dalam mewujudkan kemaslahatan dan menjauhi kerusakan di dunia maupun akhirat. Kelima unsur pokok tersebut merupakan suatu hal yang harus dijaga dalam kehidupan ini agar tercipta suatu keseimbangan. As-Syatibi membagi maqashid al-syariah menjadi 3 bagian yaitu dharuriyat, hajjiyat, tahsiniyat.

1) Dharuriyat

Merupakan keadaan di mana suatu kebutuhan wajib untuk dipenuhi dengan segera, jika diabaikan maka akan menimbulkan sesuatu yang dapat berbahaya dan berisiko pada rusaknya kehidupan manusia. Kebutuhan daruriyah menurut Imam As Syatibi (dalam jurnal Abdurrahman Kasdi Dosen STAIN KudUS), Allah telah menurunkan syariat atau aturan hukum untuk menciptkan sebuah kemaslahatan dan menghindari kemudharatan atau keburukan. Aturan- 
Kartika, et al/Jurnal Ekonomi Syariah Teori dan Terapan Vol. 6 No. 2 Februari 2019: 353-371; KEBIJAKAN KEPEMIMPINAN WALIKOTA SURABAYA DALAM MENGAMBIL KEPUTUSAN DI BIDANG EKONOMI YANG BERBASIS MAQASHID SYARIAH

aturan hukum yang Allah tentukan semata-mata untuk kemaslahatan kehidupan manusia dimuka bumi ini agar terciptanya kedamaian di dunia. Dalam buku As Syatibi, kemaslahatan dibagi menjadi tiga bagian yaitu dharuriyat (pokok), hajjiyat (sekunder), dan tahsinat (tersier). Maqashid dapat disebut dengan maslahat dharuriyat, yang kemudian terbagi menjadi lima pokok, yaitu :

1. Pemeliharaan Agama (al-din)

2. Pemeliharaan Jiwa (al-nafs)

3. Pemeliharaan Keturunan (al-nasl)

4. Pemeliharaan Harta (al-mal)

5. Pemeliharaan Akal (al-aql)

2) Hajjiyat

Dimaksudkan untuk memudahkan manusia dalam kesulitan dan juga menjadikan pemeliharaan yang lebih baik terhadap lima pokok kehidupan manusia. Hajjiyat juga biasanya disebut dengan kebutuhan sekunder atau sebagai pelengkap dan penunjang untuk kegiatan manusia.

3) Tahsiniyat

Dimaksudkan untuk sebagai pelengkap, penerang dan penghias kehidupan manusia. Agar manusia dapat melakukan yang terbaik untuk menyempurnakan pemeliharaan lima unsur pokok kehidupan manusia dan tidak bermaksud untuk menghilangkan atau mengurangi berbagai kesulitan. Tahsiniyat biasanya juga dapat disebut dengan tersier.

Kajian dalam maqashid syariah adalah kajian utama dalam filsafat hukum islam karena terdapat pertanyaan- pertanyaan kritis yang menentukan tujuan ditetapkannya sebuah hukum. Maqashid Al-Syariah telah menjadi pertimbangan dalam penetapan sebagai landasan dalam penetapan sebuah hukum yang kemudian diimplementasikan oleh para sahabat salah satunya adalah Umar bin Khattab.

Cara untuk menjaga Maqashid Syariah yang lima tadi yaitu dapat dicapai dengan cara:

Tabel 1.

\begin{tabular}{|l|l|l|}
\hline $\begin{array}{l}\text { Maqashid } \\
\text { Syariah }\end{array}$ & Contoh \\
\hline Agama & Al-wujud & shalat dan zakat \\
\hline & Al-adam & $\begin{array}{l}\text { jihad dan } \\
\text { hukuman bagi } \\
\text { orang murtad }\end{array}$ \\
\hline Jiwa & Al-wujud & $\begin{array}{l}\text { makan dan } \\
\text { minum }\end{array}$ \\
\hline Akal & Al-adam & $\begin{array}{l}\text { hukuman qishash } \\
\text { dan diyat }\end{array}$ \\
\hline Keturunan & Al-wujud & $\begin{array}{l}\text { makan } \\
\text { mencari ilmu }\end{array}$ \\
\hline & Al-adam & $\begin{array}{l}\text { had bagi pezina } \\
\text { had } \\
\text { dan muadzif }\end{array}$ \\
\hline Harta & Al-wujud & $\begin{array}{l}\text { jual beli dan } \\
\text { mencari rizki }\end{array}$ \\
\hline Al-adam & $\begin{array}{l}\text { riba, memotong } \\
\text { tangan pencuri. }\end{array}$ \\
\hline
\end{tabular}

III. METODOLOGI PENELITIAN

$$
\text { Metode penelitian yang }
$$

digunakan pada skripsi ini adalah 
kualitatif, yang artinya data yang dikumpulkan bukan berupa angka angka, melainkan data tersebut berasal dari naskah wawancara, catatan lapangan, dokumen pribadi, catatan, memo dan dokumen resmi lainnya. Sehingga, yang menjadi tujuan dari penelitian kualitatif ini adalah ingin menggambarkan realita empirik dibalik fenomena secara mendalam, rinci dan tuntas. Oleh karena itu, penggunaan pendekatan kualitatif dalam penelitian ini adalah dengan mencocokkan antara realita empirik dengan teori yang berlaku dengan menggunakan metode deskriptif.

Metode penelitian kualitatif adalah metode penelitian yang digunakan untuk meneliti pada kondisi obyek yang alamiah, di mana peneliti adalah instrument kunci, teknik pengumpulan data dilakukan secara gabungan, analisis data yang bersifat induktif, dan hasil penelitian kualitatif lebih menekankan makna dari generalisasi (Moleong, 2004).

Menurut Bogdan dan Taylor (1975:5) dalam Moleong (2004) metodologi kualitatif sebagai prosedur penelitian yang menghasilkan data deskriptif berupa kata-kata tertulis maupun lisan dari orang-orang dan perilaku yang dapat diamati. Pendekatan ini diarahkan pada latar dan individu tersebut secara holistik (utuh). Dalam hal ini tidak boleh mengisolasikan individu atau organisaso ke dalam variabel atau hipotesis, tetapi perlu juga memandangnya sebagai suatu keutuhan.
Penelitian ini bertujuan untuk mengetahui bagaimana kebijakan walikota surabaya dalam mengambil keputusan di bidang ekonomi berbasis maqashid syariah. Dalam kajian ini peneliti difokuskan kepada apa yang menjadi pertimbangan serta cara walikota surabaya dalam membuat kebijakan dalam menyelesaikan permasalahanpermasalahan yang ada di Surabaya dengan melihat dari persepektif maqashid syariah.

Peneliti menentukan informan yang dibutuhkan dalam penelitian ini adalah sebagai berikut :

1. Walikota Surabaya Ir. Tri Rismaharini, MT. (Key Informan)

2. Kepala Bidang Ekonomi Bappeko Surabaya (informan 2)

\section{Ruang Lingkup Penelitian}

Ruang lingkup penelitian dan batasan penelitian ini adalah kebijakan kepemimpinan Walikota Surabaya dalam mengambil keputusan di bidang ekonomi yang ditinjau dari aspek maqashid syariah.

\section{Jenis dan Sumber Data}

Jenis data yang digunakan dalam penelitian ini terdiri dari :

1. Data Primer yang diambil dari Key Informan (informan utama). Key informan yang dijadikan sumber data dalam penelitian ini adalah Walikota Surabaya yang sedang menjabat yaitu Dr. Ir. Tri Rismaharini, M.T. dan Kepala Bidang Ekonomi Bappeko Surabaya. 
2. Data sekunder dalam penelitian ini diperoleh dari data-data yang berasal dari buku, internet, jurnal dan sumber-sumber lain yang memiliki kaitan dengan penelitian ini.

\section{Teknik Pengumpulan Data}

Teknik Pengumpulan data menurut Sugiyono (2014 : 224) merupakan langkah yang paling strategis dalam penelitian karena tujuan utamanya adalah untuk mendapatkan data penelitian sesuai dengan standar dan harapan yang ditetapkan. Teknik pengumpulan data menggunakan multi sumber bukti (triangulasi) artinya teknik pengumpulan data yang bersifat menggabungkan dari berbagai teknik pengumpulan data dan sumber data yang telah ada.

$$
\text { Menurut Moleong (2017:330), }
$$

Triangulasi adalah teknik pemeriksaan keabsahan data yang memanfaatkan sesuatu yang lain di luar data itu untuk keperluan pengecekan atau sebagai pembanding terhadap data itu.

Menurut Patton (1987:331) dalam Moleong (2017), Triangulasi dengan sumber berarti membandingkan dan mengecek balik derajat kepercayaan suatu informasi yang diperoleh melalui waktu dan alat yang berbeda dalam penelitian kualitatif yang dalam hal itu dapat dicapai dengan jalan:

1. Membandingkan data hasil pengamatan dengan data hasil wawancara

2. Membandingkan apa yang dikatakan orang di depan umum dengan apa yang dikatakannya secara pribadi

3. Membandingkan apa yang dikatakan orang-orang tentang situasi penelitian dengan apa yang dikatakannya sepanjang waktu

4. Membandingkan keadaan dan perspektif seseorang dengan berbagai pendapat dan pandangan orang seperti rakyat biasa, orang yang berpendidikan dan menengah atau tinggi, orang berada dan orang pemerintahan

5. Membandingkan hasil wawancara dengan isi suatu dokumen yang berkaitan

Peneliti akan melakukan observasi, wawancara dan dokumentasi dalam proses pengumpulan data.

1. Wawancara

Menurut Moleong

(2017:186)

Wawancara adalah percakapan dengan maksud tertentu yang dilakukan oleh dua pihak, yaitu pewawancara (interviewer) yang mengajukan pertanyaan dan terwawancara (interviewee) yang memberikan jawaban atas pertanyaan itu. Dalam penelitian ini narasumber/informan kunci adalah Tri Rismaharini sebagai walikota Surabaya dan staf Bappeko Surabaya. 
2. Observasi

Teknik observasi menurut Namawi dan Martini (1992:74) dalam Rizki (2016) adalah pengamatan dan pencatatan secara sistematik terhadap unsur-unsur yang tampak pada objek penelitian.

3. Dokumentasi

Pada penelitian ini membutuhkan dokumentasi yang berhubungan dengan keabsahan data. Dokumen yang dapat digunakan dalam pengumpulan data seperti surat; agenda; dokumen-dokumen administratif-proposal, laporan kemajuan dan dokumen-dokumen intern lainnya; penelitian dan artikel-artikel yang muncul di media massa. Untuk menunjukkan keakuratan data, peneliti juga melampirkan foto-foto saat observasi.

\section{Teknik Analisis Data}

Penelitian ini menggunakan pendekatan analisis data yang mencakup tiga proses yaitu reduksi data, penyajian data dan verifikasi yang dikutip menurut Milles dan Huberman dalam Sugiyono (2009) sebagai berikut :

1. Reduksi Data

$$
\text { Merupakan }
$$

proses pemilihan, pemusatan perhatian, pengabstraksian dan pentransformasian data kasar dari lapangan. Proses ini berlangsung selama penelitian dilakukan, dari awal hingga akhir penelitian. Data yang diperoleh berupa hasil wawancara, data observasi dan dokumentasi yang ditransformasi dalam bentuk teks atau narasi.

2. Penyajian Data

Merupakan sekumpulan informasi tersusun yang memberikan kemungkinan untuk menarik kesimpulan dan pengambilan tindakan. Bentuk penyajian data berupa teks naratif, matriks, grafik dan bagan.

3. Verifikasi atau Menarik Kesimpulan

Dalam tahap ini, dibuat proposisi yang terkait dengan prinsip logika, kemudian mengangkatnya sebagai temuan penelitian, Lalu dilanjutkan dengan mengkaji berulang-ulang data yang ada, pengelompokan data yang telah terbentuk, dan proposisi yang telah dirumuskan. Verifikasi dilakukan untuk menguji validasi data.

\section{Teknik Uji Keabsahan Data}

Teknik uji keabsahan data adalah salah satu teknik yang penting untuk menentukan validitas dan reliabilitas data yang diperoleh dalam penelitian ini. Teknik keabsahan data yang digunakan dalam penelitian ini adalah teknik triangulasi karena menggunakan beberapa sumber data yang berasal dari wawancara dan dokumentasi. Menurut Yin (2015:105) teknik keabsahan data atau triangulasi dibagi menjadi empat metode yaitu :

1) Triangulasi Sumber 
Triangulasi sumber berguna untuk mengkaji kredibiltas data dengan cara mengecek data yang diperoleh berdasarkan beberapa sumber. Selain wawancara dan observasi, peneliti dapat menggunakan data lain seperti gambar atau foto, dokumen tertulis, arsip, dokumen bersejarah, catatan resmi, atau catatan dan tulisan pribadi.

2) Triangulasi Metode

Metode triangulasi ini dilakukan dengan cara membandingkan informasi atau data dengan cara yang berbeda untuk memperoleh informasi dan gambaran utuh mengenai informasi tertentu. Peneliti dapat menggunakan melalui metdode wawancara bebas maupun wawancara terstruktur. Peneliti juga dapat melakukan observasi dan menggunakan informan untuk memastikan kebenaran tersebut.

\section{HASIL PENELITIAN}

Kalau dilihat dari sisi ekonominya sendiri dalam hal pemenuhan anggaran, tentu Walikota Surabaya dan Pemerintah Kota Surabaya tentu mempunyai target yang besar seperti yang tertulis pada RPJMD 2016-2020. Walikota Surabaya Tri Rismaharini bekerja keras untuk mencapai suatu tujuan dalam Pertumbuhan ekonomi Surabaya. Kebijakan yang selama ini dikeluarkan adalah kebijakan yang menyangkut kesejahteraan seluruh masyarakat dan membangun Surabaya menjadi kota yang dikenal tidak hanya di kawasan Indonesia saja tetapi juga di berbagai negara dengan sisi positifnya. Seperti yang kita ketahui, Surabaya telah mengalami kemajuan yang pesat dan meraih banyak penghargaan. Pemerintah sangat berperan dalam hal ini, dan secara tidak langsung peneliti melihat dari kebijakan-kebijakan yang dibuat oleh walikota Surabaya Tri Rismaharini, mengarahkan kepada sesuatu yang dapat merubah pola pikir masyarakat menjadi maju dan dapat menciptakan suatu kedamaian dengan menjadi contoh menjadi pemimpin yang dapat bekerja sama dengan baik dengan tidak menutup kemungkinan masyarakat akan berubah menjadi masyarakat madani. Masyarakat madani adalah salah satu dari hasil dari telah terpenuhinya aspekaspek ada pada Maqashid Syariah

Tabel 2.

APBD Kota Surabaya dalam Maqashid Syariah Tahun Anggaran 2016 dan 2017

\begin{tabular}{|l|r|r|}
\hline $\begin{array}{c}\text { Maqashi } \\
\mathbf{d} \\
\text { Syariah }\end{array}$ & $\mathbf{2 0 1 6}$ & $\mathbf{2 0 1 7}$ \\
\hline Agama & 37.846 .520 .331 & 15.760 .529 .188 \\
\hline Jiwa & 2.225 .093 .910$. & 3.052 .073 .088$. \\
& 569 & 366 \\
\hline Akal & 2.141 .640 .208$. & 1.990 .324 .433$. \\
& 247 & 257 \\
\hline Keturun & 43.029 .647 .900 & 43.029 .647 .900 \\
an & & \\
\hline Harta & 68.237 .177 .937 & 74.375 .242 .758 \\
\hline Jumlah & $\mathbf{4 . 5 1 5 . 8 4 7 . 4 6 4 .}$ & $\mathbf{5 . 1 7 5 . 5 6 2 . 9 4 1 .}$ \\
& $\mathbf{9 8 4}$ & $\mathbf{4 6 9}$ \\
\hline
\end{tabular}


Jika dilihat dari tabel diatas, terlihat bahwa anggaran paling banyak adalah dari aspek Jiwa, yang termasuk dalam aspek Jiwa adalah Kesehatan, Ketahanan Pangan, Lingkungan Hidup, Perumahan/Pemukiman, Kebersihan dan Ruang Terbuka Hijau. Kesehatan termasuk dalam aspek jiwa karena masuk dalam kriteria perlindungan yang menyangkut fisik dan keselamatan seseorang, dan antara Kesehatan, Sosial, Tenaga Kerja, Kebakaran, Ketahanan pangan, Lingkungan Hidup serta Kebersihan dan Ruang terbuka hijau saling berkaitan satu sama lain dan saling mempengaruhi.

Anggaran yang terbanyak kedua adalah aspek Akal, yang termasuk dalam aspek akal adalah Pendidikan, Kebudayaan dan Pariwisata, Pemuda dan Olahraga serta Badan Arsip dan Perpustakaan. Disebut aspek akal karena berhubungan dengan ilmu yang membentuk karakter individu dan membentuk suatu identitas pada diri seseorang. Kalau sudah membentuk identitas akan mencerminkan bagaimana sifat sebagai masyarakat dan warga Surabaya yang baik dan berilmu, tidak hanya berilmu tapi juga beretika.

Anggaran yang terbanyak ketiga adalah aspek harta, yang termasuk dalam aspek harta adalah Koperasi Usaha Mikro, Kecil, Menengah, kemudian perdagangan dan perindustrian, pelayanan dan penanaman modal.

Anggaran yang terbanyak ke empat adalah aspek Keturunan, yang termasuk dalam aspek keturunan adalah pada tahun 2016 Pemberdayaan Masyarakat dan Keluarga Berencana, kemudian berganti nama atau berbeda nama pada tahun 2017 menjadi Pengendalian penduduk, Pemberdayaan perempuan dan perlindungan anak.

Anggaran yang terbanyak ke lima adalah aspek agama, yang termasuk dalam aspek agama adalah bidang kesatuan bangsa, politik dan perlindungan masyarakat serta kesejahteraan masyarakat.

Tabel 3.

Rasio Terhadap Belanja Maqashid Syariah terhadap APBD

\begin{tabular}{|r|r|}
\hline \multicolumn{1}{|l|}{$\begin{array}{l}\text { Rasio } \\
\text { Belanja } \\
\text { Syariah }\end{array}$} & $\begin{array}{r}\text { Terhadap } \\
\text { Maqashid }\end{array}$ \\
\hline 2016 & 2017 \\
\hline $0,8 \%$ & $0,3 \%$ \\
\hline $49,2 \%$ & $58,9 \%$ \\
\hline $47,4 \%$ & $38,4 \%$ \\
\hline $0,9 \%$ & $0,8 \%$ \\
\hline $1,5 \%$ & $1,4 \%$ \\
\hline $99,8 \%$ & $99,8 \%$ \\
\hline
\end{tabular}

Tabel 4.

Rasio Belanja Maqashid Syariah Terhadap APBD

\begin{tabular}{|c|c|}
\hline \multicolumn{2}{|c|}{$\begin{array}{c}\text { Rasio Terhadap } \\
\text { APBD }\end{array}$} \\
\hline 2016 & 2017 \\
\hline $0,4 \%$ & $0,1 \%$ \\
\hline $27,4 \%$ & $34,0 \%$ \\
\hline $26,3 \%$ & $22,2 \%$ \\
\hline $0,5 \%$ & $0,4 \%$ \\
\hline $0,8 \%$ & $0,8 \%$ \\
\hline $55,5 \%$ & $57,6 \%$ \\
\hline
\end{tabular}


Tabel 5.

Keterpenuhan Kebijakan Walikota pada APBD menurut Maqashid Syariah

\begin{tabular}{|l|c|c|}
\hline $\begin{array}{l}\text { Maqashid } \\
\text { Syariah }\end{array}$ & \multicolumn{2}{|l|}{ Terpenuhi /Tidak } \\
\hline Tahun & $\mathbf{2 0 1 6}$ & $\mathbf{2 0 1 7}$ \\
\hline Agama & $\sqrt{ }$ & $\sqrt{ }$ \\
\hline Jiwa & $\sqrt{ }$ & $\sqrt{ }$ \\
\hline Akal & $\sqrt{ }$ & $\sqrt{ }$ \\
\hline Keturunan & $\sqrt{ }$ & $\sqrt{ }$ \\
\hline Harta & $\sqrt{ }$ & $\sqrt{ }$ \\
\hline
\end{tabular}

$\checkmark$ : Terpenuhi

Bisa dilihat dalam tabel diatas bahwa pemenuhan Maqashid Syariah jika diukur dari rasio Anggaran Belanja Maqashid Syariah yang tertinggi adalah yang pertama dari perspektif Jiwa, kemudian yang kedua dari perspektif Akal karena dua bidang tersebut memang paling banyak rincian anggarannya akan tetapi bukan berarti bidang yang lain tidak terpenuhi. Karena walikota Surabaya telah memberi porsi kepada masingmasing anggaran dan hasil temuan ketika peneliti melakukan wawancara dengan beliau hal ini dibuktikan dengan perkataan beliau yang menyatakan bahwa semua bidang adalah utama. Karena semua adalah prioritas utama dan tidak ada yang dibagi menjadi beberapa prioritas, tapi memang jika dilihat dari bukti wawancara dengan Walikota Surabaya dan juga staf Bappeko terlihat bahwa anggaran yang paling besar adalah untuk bidang pendidikan.

Kebijakan yang dibuat oleh Walikota Surabaya, berdasarkan apa yang ada dalam aturan dan beliau taat menjalani aturan yang berlaku. Beberapa sikap yang ditunjukannya merupakan salah satu bentuk dari pengaplikasian dari Maqashid Syariah. Hal ini dibuktikan dari perasaan damai dari masyarakat Surabaya serta tidak ada perpecahan serta sifat mandiri dari masyarakat Surabaya sendiri yang punya keinginan untuk maju dan sebagai pemimpin, Risma merupakan sosok yang disegani masyarakatnya.

\section{Implementasi Kepemimpinan Walikota} dalam Pemerintahan Kota Surabaya

Implementasi manajemen kepemimpinan Walikota Surabaya Ibu Tri Risma harini sangat diperlukan dalam mencapai tujuan sebuah pemerintahan kota Surabaya. Dari pembahasan di atas dapat kita lihat bahwa implementasi kepemimpinan dalam sebuah organisasi harus ditopang dengan karakter-karakter kepemimpinan (leadershipcharacters)dan prinsip-prinsip kepemimpinan (leadership principles) yang melekat pada diri pemimpin.

Kedua hal ini dapat disebut sebagai bahan dasar kepemimpinan (leadership ingredient). Dari hasil pengamatan dan wawancara dengan walikota tersebut, kepemimpinan beliau telah menunjukkan kekuatan dalam upaya memenuhi prinsip prinsip kepemimpian bahkan kepemimpinan religiulitas; seperti amanah, fathom, tabligh dan siddiq telah diupayakan untuk ditaati dan dijalankan.

Melalui fungsi panutan(role modeling) walikota telahmembudayakan (culturing) karakter dan prinsip 
Kartika, et al/Jurnal Ekonomi Syariah Teori dan Terapan Vol. 6 No. 2 Februari 2019: 353-371; KEBIJAKAN KEPEMIMPINAN WALIKOTA SURABAYA DALAM MENGAMBIL KEPUTUSAN DI BIDANG EKONOMI YANG BERBASIS MAQASHID SYARIAH

kepemimpinan tersebut di kalangan anakbuah (followers). Proses pembudayaan ini dilakukan dengan menginternalisasikan karakter dan prinsip kepemimpinan tersebut keseluruh anak buah sehingga mereka memahami, menghayati, dan melakukannya. Ketika proses pembudayaan ini berlangsung missal dan mencakup seluruh orang di dalam organisasi ,pemerintahan kota beliau berharap dapat membentuk iklim kepemimpinan (leadership climate) dalam organisasi. Iklim kepemimpinan ini memungkinkan organisasi menjalankan siklus manajemen (planning, organizing, actuating, dancontrolling) secaraefektif.

Karakter dan prinsipkepemimpinan yang dibangun dengan baik dan mulia akan menciptakan iklim kepemimpinan yang kondusif. Iklim yang kondusif ini pada akhirnya akan mengefektifkan organisasi dalam mengeksekusi strategi dan mendorong tercapainya kinerja yang luar biasa. Sebaliknya apabila karakter dan prinsip kepemimpinan yang dibangun kurang baik, iklim yang tercipta akan bersifat destruktif, sehingga organisasi akan terkendala dalam mengeksekusi strategi, sehingga kinerja yang diraih menjadi buruk. Demikianlah, apabila manajemen kepemimpinan ini benarbenar dilaksanakan dengan baik, maka organisasi akan dapat mencapai tujuannya denganl ebih baik.

Menurut Aula fahruddin dari hasi Ipenelitiannya (Aula Fahrudin, 2016) bahwa dalam kepemimpinan walikota Surabaya banyak inovasi dan karakter kepempinan yang terbentuk Dalam sisi hambatan, penelitian tersebut juga menemukan hal baru berbeda dari teori dan konsep yang dibawa oleh Mulgan dan Albury. Penelitian tersebut menemukan faktor tekanan politik yang tinggi menjadi salah satu hambatan terciptanya sebuah program inovasi di daerah. Banyak kasus terjadi konflik kepentingan yang ada di ranah politik praktis. Seorang pemimpin dituntut untuk memastikan kestabilan politik guna berjalannya suatu kebijakan. Selain itu, hambatan yang masih menjadi kunci bahasan adalah keterbatasan Sumber Daya Manusia. Untuk mengelola kota sebesat Surabaya dibutuhkan tidak hanya ide atau gagasan yang inovatif, namun ketersediaan para pelaksana di lapangan. Setiap pemimpin memiliki cara dan kekhasan dalam memimpin dan Risma salah satu yang bisa dicontoh bagi pemimpin daerah lain. Tentunya agar muncul regenerasi pemimpin-pemimpin inovatif di berbagai daerah.

\section{KESIMPULAN}

Berdasarkan penelitian yang telah dilakukan, dapat disimpulkan bahwa :

1. Walikota Surabaya Tri Rismaharini membuat kebijakan yang secara tidak langsung berpengaruh pada masyarakat surabaya dan didasarkan karena Risma sudah mengimplementasikan kepemimpinan yang baik menurut agama dan juga aturan yang berlaku secara adil tanpa pandang bulu. 
2. Religiusitas dan pemahaman Risma tentang apa pun yang dia lakukan sebagai pemimpin akan dipertanggungjawabkan oleh Allah SWT, secara langsung maupun tidak langsung merupakan implementasi dari Maqashid Syariah.

Saran

Berdasarkan penelitian yang telah dilakukan, maka penulis memberi beberapa masukan yaitu :

1. Bagi Pemerintah

Untuk menjadi yang lebih baik lagi dalam memuat kebijakan, terutama bersinergi dalam kepentingan masyarakat. Semoga pemerintah daerah lain dapat termotivasi untuk menciptakan karya-karya seperti yang dilakukan oleh pemimpin Surabaya saat ini.

2. Bagi Masyarakat

Untuk membantu pemerintah mewujudkan kesejahteraan bersama, serta membangkitkan kesadaran masyarakat bahwa kesejahteraan akan dicapai apabila ada hubungan timbal balik antara masyarakat dan pemerintah. Masyarakat sendiri dapat meringankan beban pemerintah setidaknya dengan mematuhi peraturan yang ada dan tidak menimbulkan kericuhan dan keributan.

3. Bagi Penelitian Selanjutnya Agar dapat membahas lebih dalam dan dapat melengkapi penelitian yang jauh dari sempurna ini. Karena kesempurnaan hanyalah milik Allah dan ketidaksempurnaan merupakan milik kita sebagai manusia.

\section{DAFTAR PUSTAKA}

Ad-Dumaiji,Abdullah.2016.Imamah

'Uzhma: Konsep Kepemimpinan Islam. Jakarta: Ummul Qura

Effendie,H. 2017.Keuangan Negara Suatu Tinjauan Komprehensif dan Terpadu. Surabaya: Airlangga University Press

Fahmi, Irham. 2012. Manajemen Kepemimpinan : Teori \& Aplikasi. Cetakan Kesatu. Bandung : Alfabeta.

Herabudin. 2016. Studi Kebijakan Pemerintah : Dari Filosofi ke Implementasi. Bandung : CV Pustaka Setia

Indiahono, Dwiyanto. Kebijakan Publik : Berbasis Dynamic Policy Analysis. Yogyakarta : Gava Media

Jusmaliani dkk.2005.Kebijakan Ekonomi Dalam Islam.Yogyakarta: Kreasi Wacana

juragansejarah.blogspot.com/2013/04/sej arah-kota-surabaya-lengkap.html Karnaen A. Parwataatmadja, op.cit., hal. 11-12.

Karnaen A. Parwataatmadja, op.cit., hal. 13-14.

Karim, Adiwarman A. 2001. Ekonomi Islam : Suatu Kajian Kontemporer. Cetakan pertama Hal 25. Jakarta: Gema Insani Press 
Mustafa Anas Zarqa, Islamic Economic: An Approach to Human Welfare, Reading in the Concept and Methodology of Islamic Economics (Selangor Darul Ehsan: Pelanduk Publication, 1989) hal. 35-36.

Moleong, Lexy J. 2004. Metode Penelitian Kualitatif. Bandung: Remaja Rosda Karya

Parwataatmadja, Karnaen

A. Parwataatmadja. Sejarah Pemikiran Ekonomi Islam, bahan ajar pada Program Pascasarjana Universitas Indonesia, Program Studi Kajian Timur Tengah dan Islam, Kekhususan Ekonomi dan Kevangan Syariah, 2002, hal 7-8.

Pasalong, harbani. 2008. Kepemimpinan Birokrasi. Bandung : Alfabeta

Pitasari, Ervina. 2018. Kisah, Perjuangan \& Inspirasi Tri Rismaharini. Yogyakarta: Checklist

Rismaharini,Tri.2015.Kota Hijau dalam Dimensi Inovasi dan Manusia.Surabaya:ITS Press Institut Teknologi Sepuluh Nopember

Sjafrizal. 2012.Ekonomi Wilayah dan Perkotaan.Jakarta: PT Raja Grafindo Persada

Sarjanaku.com (diakses pada : Oktober 2018)

Slater, Robert. 2001. Jack Welch and The GE Way : Wawasan Manajemen dan Rahasia Kepemimpinan CEO Legendaris (Terjemah oleh Fandy Tjiptono). Edisi I. Yogyakarta : ANDI.
RPJMD Kota Surabaya Tahun 2016-2020

Staffnew.uny.ac.id : BukU dasar-dasar kebijakan publik (diakses pada september 2018)

Surabaya.go.id (di akses: pada Desember 2018)

Umar Chapra, The Islamic Vision of Development in the Light of Maqasid Al Shariah, (IDB, 2008), hal.7.

Wahab, Solichin Abdul. 2004. Analisis kebijaksanaan:dari formulasi ke implementasi kebijaksanaan negara. Hal 1-2 Jakarta: bumi aksara

William N. Dunn. 2003. Pengantar Analisis kebijakan publik. Terjemahan Hal: 24-25 Yogyakarta: Gadjah Mada University Press.

Winarno, Budi. 2005.Teori dan Proses Kebijakan Publik. Yogyakarta:Media Press

Yukl,gary. 2005. Kepemimpinan dalam Organisasi. Jakarta: PT Indeks Kelompok Gramedia 